JOURNAL OF BUSINESS

MANAGEMENT AND ACCOUNTING

http://e-journal.uum.edu.my/index.php/jbma

How to cite this article:

Akinwale A. A., Shadare, A. O. \& Aliyu, M. O. (2021). Breach of psychological contracts and discretionary behaviour in Nigerian academics. Journal of Business Management and Accounting, 11(1), 21-44. https://doi.org/10.32890/jbma2021.11.1.2

\title{
BREACH OF PSYCHOLOGICAL CONTRACTS AND DISCRETIONARY BEHAVIOUR IN NIGERIAN ACADEMICS
}

\author{
${ }^{1}$ Akeem Ayofe 'Akinwale, ${ }^{2}$ Adetunji Oluseyi Shadare \& \\ ${ }^{3}$ Mustapha Olanrewaju Aliyu \\ ${ }^{1 \& 2}$ Department of Employment Relations and \\ Human Resource Management, \\ Faculty of Management Sciences, \\ University of Lagos, Akoka, Nigeria \\ ${ }^{3}$ Department of Industrial Relations and \\ Personnel Management, \\ Faculty of Management Sciences, \\ University of Ilorin, Nigeria
} ${ }^{3}$ Corresponding author: aliyu.om@unilorin.edu.ng

Received: 8/6/2020 Revised: 17/8/2020 Accepted: 9/9/2020 Published: 31/1/2021

\begin{abstract}
This study explored the breach of psychological contracts and discretionary behaviour by Nigerian academics. A survey was employed to elicit information from 378 academics that were randomly selected from 7,131 academics in federal universities in the North-Central Nigeria. The results from the hypotheses testing revealed that most of the universities in the North-Central zone did
\end{abstract}


not comply with the psychological contract (as supported by the negative results from statistical estimates and Levene's t-values). There was a positive correlation between breach of psychological contract and organisational citizenship behaviour (OCB) as well as positive relationship between breach of psychological contract and deviant workplace behaviour (DWB) $(\mathrm{r}=0.196 ; \mathrm{p}<0.05$ and $\mathrm{r}=0.126$; $\mathrm{p}<0.05$, respectively). The breach of psychological contract has influenced academics in different ways showing a tendency for OCB and DWB. Unfortunately, the tendency for DWB outweigh that of OCB. Therefore, academics who uphold OCB despite the perceived BPC should be encouraged to sustain their good behaviour.

Keywords: Psychological contract, breach, organisational citizenship behaviour, deviant workplace behaviour, North-central Nigeria.

\section{INTRODUCTION}

The concept of psychological contract has been accepted by scholars and experts in the fields of social and management sciences as a critical mechanism for understanding the behavioural patterns and dispositions of employees in organisations. Its acceptance in scholarship is a consequence of various qualitative and quantitative evidences supporting the concept as a fundamental element for evaluating discretionary behaviour of employees. Psychological contracts are sets of unwritten expectations about the promises made by employers to employees at the beginning of their engagement (Jaclyn, Richard \& Ann, 2010). These include healthy environments, opportunity for growth and development, healthy relations with coworkers, fair evaluation, recognition for innovation, and emotional support, among others. Employers on the other hand expect employees' sincerity, punctuality, developing new skills, hard work, and readiness to provide extra hours as and when required (Kamil \& Ahmad, 2018). However, when there is mismatch between what is desired and what is offered, the breach of psychological contract (BPC) has occurred (Anyim, Obisi \& Aliyu, 2018). This might facilitate the role of employees' emotions and attitudes in driving their behaviours in the workplace.

Previous studies revealed that performance is considered a function of employees' workplace attitude and behaviour (Bambale \& Shamsudin, 
2015; Dunlop \& Lee, 2004). Two major components of overall job performance are task behaviour and discretionary behaviour. Meanwhile, organisational citizenship behaviour (OCB) and deviant workplace behaviour (DWB) are major forms of discretionary behaviour commonly found in the literature (Pradhan \& Pradhan, 2016). Therefore, employees engage in either OCB, which increases organisational effectiveness, or DWB, which impairs organisational efficiency. Implicitly, these behaviours reflect in opposite directions because the former benefits the organisation while the latter harms it. Meanwhile, the perceived BPC may be responsible for job flexibility and mobility of academics in Nigerian universities. For instance, Nigeria has 165 universities comprising 43 federal universities, 47 state universities, and 75 private universities (NUC, 2018).

Despite the proliferation of universities in Nigeria, none has featured in the first 1000 universities in the world according to the 2019 Webometric Ranking. This ranking is based on the quality of curriculum (10\%), quality of academics (40\%), research output (40\%), and per capital performance $(10 \%)$. In addition, the 2019 report from Times Higher Education showed that no Nigerian federal university is listed in the first 600 universities in the world. The parameters used, include, teaching (30\%), research output (30\%), citations (30\%), global outlook $(7.5 \%)$, and industry income $(2.5 \%)$. On the African continent, only five out of 43 federal universities made it in the list of the top 50 universities in Africa. These are the University of Ibadan (ranked 17th), University of Nigeria (25th), Obafemi Awolowo University (38th), University of Lagos (41st), and Ahmadu Bello University (44th). Considering the appalling conditions and shortcomings, it is necessary to examine perceive breach of psychological contract and discretionary behaviour among academics of federal universities in the North-Central Nigeria.

It is alleged that the repressive practices of the Nigerian government and failure to honour collective agreement, exposes academics to threats locally and internationally. In addition, the academics' strength and provision of basic facilities does not commensurate with the geometric growth in the rate of students' enrolment (Anyim et al., 2018). The lackadaisical attitude of successive governments towards the implementation of Memorandum of Understandings (MoUs) and Memorandum of Actions (MoAs) is indeed an evidence of a BPC, and 
this may have consequences on the commitment and performance of academics in federal universities. The government on the other hand, expresses dissatisfaction over nonchalant attitude of some academics and some universities in Nigeria.

Hence, researching into psychological contract, its breaches, and implications in Nigerian universities is therefore necessary and timely, considering the contemporary problems plaguing Nigeria universities. It is imperative therefore to scientifically investigate the relationship between the breaches of psychological contracts and discretionary behaviour among academics of federal universities in Nigeria. Previous studies revealed that there is a need for more scientific studies on the types of discretionary behaviour that are mostly exhibited by academics when psychological contracts are breached (Anyim et al., 2018; Chowdhury, 2015; Omar, Halim, Zayed, Farhadi, Nasir \& Khairudin, 2016). Therefore, this study examined the influence of psychological contract breaches on discretionary behaviour of academics employed in federal universities in the NorthCentral Nigeria.

As of 2018, there were 43 federal universities in the Nigerian Federation (NUC, 2018). Federal universities were chosen for the study because they are the oldest and the largest government-funded tertiary institutions in Nigeria. Also, federal universities in North-Central location was chosen, because they less comply with psychological contracts, and are more prone to poor work environments, the high attrition rates, under-funding, and low quantity and poor quality of research in the study areas (Asamu, Abiola, Ogandimma \& Bamidele, 2019).

\section{Objectives of the Study}

The objectives that were established for this study were,

i. to determine the relationship between the location of federal university and organisational compliance with psychological contracts in the North-Central Nigeria, and

ii. to examine the association between perceived breach of psychological contracts and the spread of discretionary behaviour among academics of federal universities in the North-Central Nigeria. 


\section{LITERATURE REVIEW}

\section{Breach of Psychological Contracts}

The term was first introduced in Rousseau's seminal work in 1989 (Rousseau, 2003), the study stated that psychological contracts impact employee's work cognitions and behaviour when organisations fail to respond to an employee's contribution in ways the individual believes they are obligated to do so. Ugwu and Orji (2013) argued that an employee could cognitively perceive that promises are not fulfilled, without strong emotional responses to the event. Hence, "the cognitive phenomenon of failure to fulfil promises, which represents the breach of the psychological contract and the emotional phenomenon of response to the breach of the psychological contract that represent violation. However, breach of psychological contract could result in a combination of feelings of disappointment and anger that cause the employee to feel indignation, resentment, and outrage because he/she has been mistreated and betrayed" (Hasuli \& Elaine, 2018).

\section{Discretionary Behaviour}

The actions of employees' behaviour at a workplace, either good or bad, constitute their work behaviour. In an organisation, employees engage either in $\mathrm{OCB}$, which increases organisational effectiveness (Norman, Avey, Nimnicht, \& Pigeon 2010), or in DWB which impairs organisational efficiency (Omar et al., 2016). Implicitly, these behaviours reflect in opposite directions because the former benefits the organisation while the latter harms it. Originally, Organ (1988) conceptualised the term OCB as the discretionary behaviour that is exhibited by an individual and not formally recognised by the organisational system, which aims at benefiting the organisation to which the individual belongs to.

\section{Organisational Citizenship Behaviour}

Organ (1988) explained that there are different forms of OCB that can be exhibited by employees, such as (i) Altruism - helping other members of the organisation in carrying out their official duty, (ii) Courtesy - treating other employees politely and preventing likely hitches from workplace relationships, (iii) Sportsmanship - having a 
positive attitude towards work without complaint or petty grievance, (iv) Civic Virtue -responsibly participating in political life of the organisation (e.g., attending meetings/functions that are not required but are helpful for the organisation), and (iv) Conscientiousness carrying out in-role behaviour well beyond the minimum required levels (e.g., working long hours, voluntarily doing things besides duties, following the rules of the organisation, and never wasting time).

\section{Deviant Workplace Behaviour}

Bennett and Robinson (2000) described DWB as a voluntary behaviour that violates significant organisational norms, which threatens the wellbeing of an organisation or its members. Figure 1 shows the dimensions of DWB, consisting of (1) political deviance, (2) production deviance, (3) personal aggression, and (4) property deviance. Political deviance is a behaviour targeted at individuals which involves engagement in social interaction that puts other individuals at a personal or political disadvantage (Bennett \& Robinson, 2003; Gomam, Vem, \& Panshak, 2017). Specifically, it includes behaviour such as gossip, rumour spreading, and favouritism (Hastuti, Noor, Osman, \& Lubis, 2017). Production deviance is less severe behaviour targeted at the organisation (Pradhan \& Pradhan, 2016). This includes things such as taking excessive breaks, frequently calling in sick, intentionally working slowly, and generally violating norms regarding the minimal quality and quantity of work standards. Personal aggression is a more severe behaviour targeted at individuals such as harassment, verbal attacks, and threats to cause physical harm (Waseem, 2016). Property deviance, like personal aggression, is another more severe behaviour but is targeted at the organisation, and includes deviant actions such as stealing, sabotage, and vandalism.

\section{Nigerian University System}

In Nigerian universities, deviant behaviours have also contributed immensely to the problem of low quality education and as a result, such behaviours have negative impact on the quality of graduates from these universities (Anyim et al., 2018). Omar et al. (2016) argued that the results of these behaviours lead to severe conflicts, which do not only lead to extended academic sessions, and destruction of lives and property, it also renders the academic environments unsuitable and 
unsafe for serious academic activities and also impedes educational development as people are denied the capability to develop new ideas, initiatives and innovations as they cannot engage in any meaningful thinking or research in an environment fraught with conflict. Faborode (2016) enumerated other factors contributing to the decline in quantity and quality of research, which include frequent industrial actions and poor motivation. Indeed, for the quantity and quality of research outputs to make the desired impacts on national development, integration of information technology in teaching and research is required, as well as the commercialisation of research results.

\section{Theoretical Framework}

This section examines the various theories concerning the breach of psychological contract and discretionary behaviour among academics. Each theory shows the underlying assumptions, the main propositions of the theory, the main criticisms, and justification for the theory. The study employed Social Exchange Theory (SET) by Blau (1964), and Theory of Planned Behaviour (TPB) by Ajzen in 1985 (Ajzen \& Fishbein, 2005). SET and TPB provide a basis for an understanding of the subject matter of this study.

Social exchange theory was propounded by social psychologists (Blau, 1964). The theory is used to understand the phenomena of employeeemployer relationships and psychological contract, which may differ from one employee to another. Thus, social exchange theory explains the motivation for a particular behaviour. The theory suggests how human behaviour evolves and how it differs between individuals. For instance, employees may choose to engage in OCB to reciprocate fair treatment from the organisation or withhold such behaviour by engaging in DWB, if they feel unfairly treated. When employees perceive that the obligations of the organisation compared to their own contributions are not fulfilled, they will reciprocate by adjusting their attitudes and behaviour. Imbalance in the psychological contract has frequently been operationalised as violation or breach of contract. Ajzen developed the Theory of Planned Behaviour (TPB), and it was an expanded version of the Theory of Reasoned Action (TRA) proposed by Fishbein and Ajzen in 1980 (Ajzen \& Fishbein, 2005). The main theme of this theory is that behavioural intention is the best way to predict and explain a person's behaviour. TPB is a cognitive idea of human behaviour that focuses on prediction and understanding 
of clearly defined behaviour. The theory states that people act by their intentions and perceptions of control over their behaviour, while intentions are influenced by attitudes toward the behaviour, subjective norms, and perceptions of behaviour control (Ajzen \& Fishbein, 2005). According to the theory, if people evaluate the suggested behaviour as a positive attitude, and if they think their significant others want them to perform the behaviour, this results in higher intention and they are likely to do so.

In summary, social exchange theory is not adequate to explain the circumstances surrounding breach of psychological contracts. In this case, equity theory was considered suitable for an understanding of a comparative analysis of input and output as well as the likely reactions to perceived inequity or breach of psychological contract. Moreover, TPB is used to explain the contexts of discretionary behaviour from the perspectives of subjective norms, perceived behavioural control, and attitudes toward the behaviour. The salient points in TPB can be reinforced by the application of expectancy theory. Therefore, the theoretical framework of this study was based on integration of the main ideas in the theory of social exchange, equity theory, the theory of planned behaviour and expectancy theory.

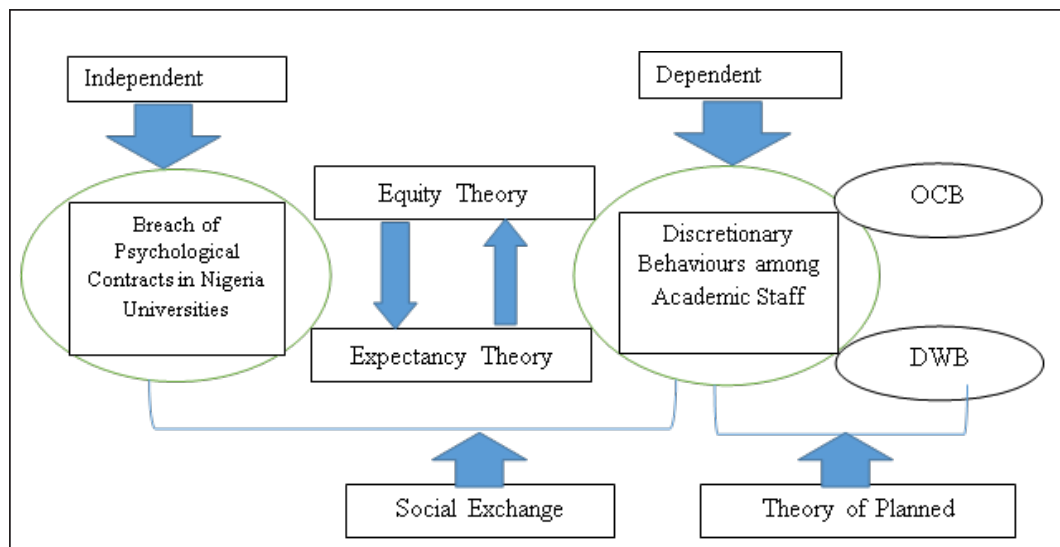

Note: Authors conceptualisation from the study (2019)

Figure 1: Conceptual framework developed for the study

The framework further suggests that when academics experience an unfavourable treatment or perceived inequity from their employer, 
they might reciprocate by engaging in an unproductive and deviant workplace behaviour by expressing through anger or reducing commitment toward institution goals. Similarly, when academics get a favourable treatment or perceived equity, it is required of them to offer a favourable treatment in return by showing citizenship behaviour. Although, this is assuming that the values and perceptions differ from person to person at different times and places. For instance, when the university reneges on its promises or failed to do what they ought to do for the academics, many academics may tend to do nothing and accept the results of the breach. As a result, the following null hypotheses were formulated for this study.

$\mathrm{H}_{01}$ There is no significant relationship between the location of a university and the level of compliance with psychological contracts in the federal universities

$\mathrm{H}_{02}$ The perceived breach of psychological contracts is not significantly associated with the spread of discretionary behaviour among academics in federal universities.

\section{METHODOLOGY}

A descriptive design was adopted to elicit the needed information directly from the target population across federal universities in the North-Central Nigerian region. The design attempted to provide an accurate description of a particular phenomenon at one point in time. The choice of descriptive design was premised on its applicability to use a wide variety of quantitative and qualitative methods to investigate one or two variables, which cannot be manipulated but observed and measured (Bichi, 2004). Descriptive research is an appropriate choice when the research aim is to identify characteristics, frequencies, trends, correlations, and categories (Fisher, 2004).

The population for this study comprised academics in all federal universities operating in North-Central Nigeria. As at 2018, there were seven federal universities in North-Central Nigeria (NUC, 2018). Federal universities were chosen for this study because they are expected to present a fair and accurate view of their operational strategies since they are owned, financed, and controlled by the Federal Government. 


\section{Table 1}

Population of the Study

\begin{tabular}{|c|c|c|c|c|c|c|}
\hline \multirow[t]{2}{*}{$\mathbf{S} / \mathbf{N}$} & \multirow[t]{2}{*}{ Universities } & \multicolumn{4}{|c|}{ No. of Academics } & \multirow[t]{2}{*}{ Total } \\
\hline & & $\begin{array}{l}\text { Professorial } \\
\text { Cadre }\end{array}$ & $\begin{array}{c}\text { Senior } \\
\text { Lecturers }\end{array}$ & Lecturers & Others & \\
\hline 1 & $\begin{array}{l}\text { University of Ilorin, } \\
\text { Kwara State }\end{array}$ & 406 & 267 & 532 & 301 & 1,506 \\
\hline 2 & $\begin{array}{l}\text { University of Jos, } \\
\text { Plateau State }\end{array}$ & 305 & 200 & 411 & 259 & 1,175 \\
\hline 3 & $\begin{array}{l}\text { Federal University of } \\
\text { Technology, Minna }\end{array}$ & 195 & 204 & 311 & 262 & 972 \\
\hline 4 & $\begin{array}{l}\text { University of Abuja, } \\
\text { Gwagwalada }\end{array}$ & 330 & 288 & 387 & 371 & 1,376 \\
\hline 5 & $\begin{array}{l}\text { University of } \\
\text { Agriculture, Makurdi }\end{array}$ & 177 & 223 & 322 & 261 & 983 \\
\hline 6 & $\begin{array}{l}\text { Federal University, } \\
\text { Lafia, Nasarawa State }\end{array}$ & 76 & 114 & 240 & 202 & 632 \\
\hline 7 & $\begin{array}{l}\text { Federal University, } \\
\text { Lokoja, Kogi State }\end{array}$ & 58 & 93 & 185 & 151 & 487 \\
\hline
\end{tabular}

Total

Sources: 2019 NUC Record

2019 National Bureau of Statistics

2019 Sampled Universities in the North-Central Nigeria

Based on the study population, the study is therefore limited to federal universities in the North-Central Nigeria. Academics were considered in this study because the quality, economic value, and reputation of any institution depends on the quality of their academics in terms of acquisition of new knowledge, engendering innovation, teaching quality, research output, citations, and global outlook (Essays UK, 2018). Hence, the sample size was determined using 1973 Guilford and Fruchter formula (Anderson, 2009; Bichi, 2004),

where:

$$
\mathrm{n}=\frac{\mathrm{N}}{\sum\left[\left(1+\mathrm{N}(\mathrm{e})^{2}\right]\right.}
$$

$\mathrm{n}=$ the desired sample size to be determined

$\mathrm{N}=$ total population, and

$\mathrm{e}=$ accepted error limit $(0.05)$ on the basis of $95 \%$ confidence level. 
Therefore, $\mathrm{N}=7,131 \quad \mathrm{e}=0.05 \quad \mathrm{n}=$ unknown sample size

$$
\begin{aligned}
& \mathrm{n}=\frac{7,131}{\left[1+7,131(0.05)^{2}\right]} \\
& \mathrm{n}=\frac{7,131}{[1+7,131(0.0025)]} \\
& \mathrm{n}=\frac{7,131}{[1+17.83]} \\
& \mathrm{n}=\frac{7,131}{18.83}
\end{aligned}
$$$$
\mathrm{n}=378 .
$$

The sample size was apportioned to each university based on Proportionate Affixation Criterion (PAC) (Animasahun \& Aremu, 2017; Fisher, 2004). This was adopted for estimating and distributing proportion of academics among the seven federal universities in the North-Central Nigeria, as calculated in Table 2 using the following equation.

Population of the sampled university $\mathrm{x}$ sample size Total population 


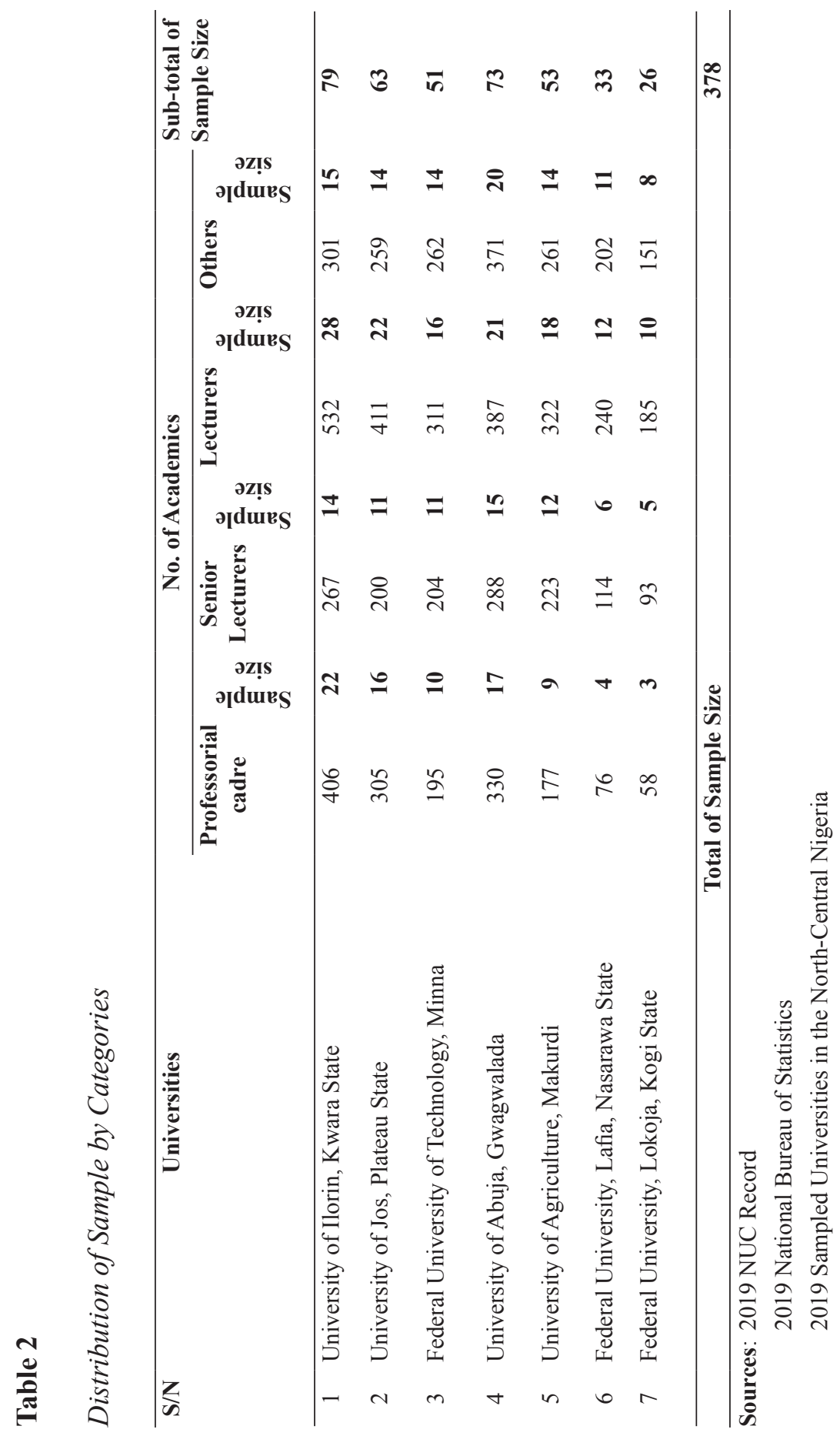


The use of probability sampling technique is justified because covering all the clusters is undoubtedly going to be very costly and time demanding. Hence, the choice of simple random sampling technique was used to select each of the respondents from the quota allotted to each of the faculties in the selected universities. The number of academics selected from a particular level was proportional to the stratum's share of the total population. The study adopted a mixed method approach to combine the use of quantitative and qualitative methods to allow extraction of analytical, narrative, and descriptive data to explain the variations between BPC and discretionary behaviour among academics. The adoption of both methods enabled the researcher to tap the advantages of both methods and to use the strength of one to support the weakness of the other. The mixed method was deemed appropriate because qualitative instruments will provide more in-depth themes and perspectives on the issues which the quantitative instrument might not be able to (Salau, 2017).

The primary data was obtained through a structured questionnaire and In-Depth Interview (IDI). The use of primary data was justified because variables under examination are personal issues and require respondents to give clear information about their views. The researcher therefore went to each faculty and randomly distributed the assigned number of questionnaires across the university. This is because the researcher noted that academics are not easily accessible even when they are on campus, as it is difficult to pin them down to a specific location. They could be teaching in the classroom, reading in the libraries, or experimenting in the laboratories. Qualitative data were obtained through the in-depth interviews (IDIs). In the course of the interviews, the objectives of the study were explained to the respondents. The interview topics were facilitated in a conversational flow that accorded interviewees the freedom to discuss what they want without any fear.

Content validity was adopted to authenticate that the research instruments actually measured exactly what they were designed to measure. The content validity ensured that the items were certified valid by senior colleagues in the department who were experts in this field of study. In determining the reliability of this research instrument, the Cronbach's Alpha was used to measure the reliability of the instrument taking into consideration the rule of Cronbach's Alpha, which states that the result can be deemed reliable when the research instrument yields a figure greater than 0.7 . The results are depicted in Table 3. 
Table 3

Cronbach's Alpha Reliability Coefficients of Pilot Study

\begin{tabular}{llccc}
\hline S/N & \multicolumn{1}{c}{ Variables } & $\begin{array}{c}\text { No. of } \\
\text { Items }\end{array}$ & $\begin{array}{c}\text { Cronbach's } \\
\text { Alpha }\end{array}$ & $\begin{array}{c}\text { No. of } \\
\text { Respondents }\end{array}$ \\
\hline 1 & Breach of Psychological contracts & 15 & 0.701 & 20 \\
2 & $\begin{array}{l}\text { Organisational Citizenship } \\
\text { Behaviour }\end{array}$ & 5 & 0.818 & 20 \\
3 & \begin{tabular}{l} 
Deviant Workplace Behaviour \\
\hline
\end{tabular} & 4 & 0.711 & 20 \\
\hline
\end{tabular}

From the pilot study, the Cronbach's Alpha Coefficient was 0.701, 0.818 , and 0.711 for the scales measuring breach of psychological contracts, organisational citizenship behaviour, and deviant workplace behaviour, respectively. A high value of Cronbach's alpha test indicates that the stability, dependability, and predictability of the measuring instrument is very certain (Bichi, 2004).

Upon completion of data collection, a combination of both descriptive and inferential statistics were employed as methods of data analysis. The descriptive statistics, which included mean, median, standard deviation, frequencies, percentages, and cross-tabulation were used to describe the socio-demographic characteristics of the respondents. Multivariate correlation analysis was employed to analyse the relationships among the independent variable, the breach of psychological contracts, and dependent variable, discretionary behaviour. These techniques were used to analyse the structural relationships among the construct variables and the structural relationship between measured variables and latent variables (Bordens \& Abbott, 2012; Hill, Birley \& McDougall, 2003). It offers more meaningful and valid results, while other methods of analysis often result in less clear conclusions, and would require several separate analyses.

\section{RESULTS}

Results from data collected were presented with inferential statistical methods like non-parametric correlational analysis in the process of testing the hypotheses with the aid of SPSS software, version 23 , due to its suitability in quantitative studies. Interpretation of the 
results of the analysis follows each of the hypotheses and also, where necessary, selected results from the demographic data collected were used to justify the results of the analysed hypotheses. The results of qualitative data were presented and analysed using thematic analysis. The analysis of quantitative and qualitative data were integrated for a better understanding of the subject matter under investigation.

\section{Hypothesis One}

Levene's Test was used to test the significance of all locations of universities associated with the level of compliance in psychological contracts, by dividing the factor-level mean square by the residual mean square, to obtain an $\mathrm{F}_{0}$ value. Table 4 reveals the negative result for statistical estimate and $\mathrm{t}$-values that showed most of the universities in the North-Central zone did not comply with psychological contract (or instance, Abuja -5.3825, Ilorin -9.1507, Jos -6.6875, Lafia -6.0000, Lokoja -4.6667, Makurdi -4.6667, Minna -0.7273). Although, the degree level varies for instance, the University of Ilorin showed the highest-level of non-compliance with level of psychological contract while Federal University of Minna had the lowest level of noncompliance with psychological contract.

\section{Table 4}

Association between the Location of a University and Organisational Compliance with Psychological Contracts in Federal Universities

\begin{tabular}{ccccc}
\hline Constructs & Estimate & Std. Error & t-value & $\operatorname{Pr}(>|\mathbf{t}|)$ \\
\hline (Intercept) & 43.0000 & 1.8605 & 23.111 & $<2 \mathrm{e}-16^{* * *}$ \\
Abuja & -5.3825 & 2.2143 & -1.754 & 0.397074 \\
Ilorin & -9.1507 & 2.5949 & -3.526 & $0.000481^{* * *}$ \\
Jos & -6.6875 & 2.9048 & -2.302 & $0.021947 *$ \\
Lafia & -6.0000 & 3.4202 & -1.754 & 0.080318 \\
Lokoja & -4.6667 & 3.5083 & -1.330 & 0.184381 \\
Makurdi & -2.5111 & 2.9613 & -0.848 & 0.397074 \\
Minna & -0.7273 & 2.9816 & -0.244 & 0.807447 \\
\hline
\end{tabular}

Levene's Test for Equality of Variances: Signif. codes: 0 ‘***’0.001 ‘**’0.01 ‘*’ 0.05 ' 0.1 ' 1

Residual standard error: 15.45 on 328 degrees of freedom

Multiple R-squared: 0.04927, Adjusted R-squared: 0.03188

F-statistic: 2.833 on 6 and $328 \mathrm{DF}$, p-value: 0.01057

Source: This Study 
Therefore, the report showed that not all federal universities in the North-Central zone comply with the level of psychological contracts, with the exception of the means of dispatching file/letters (information sharing), and treatment of academics as principal components of psychological contracts, which tested positive in the Levene's test thus exhibiting significant relationships with the location of federal universities in the North-Central region. The F-statistic was 2.833 from the summary in Table 4, showing significant relationship with the p-value of 0.01057 , which is less than the alpha level of 0.05 , thus the variables under consideration are jointly significant. Therefore, the null hypothesis is rejected while the alternative hypothesis is accepted, so there is a significant effect between the location of the university and organisational compliance with psychological contract in the federal universities in North-Central Nigeria.

\section{Hypothesis Two}

The result in Table 5 shows that all the variables significantly influence the probability of that academics will react to the perceived breach of psychological contract, but the direction of influence differs. For instance, Graduate Assistants and Assistant Lecturers are seen to have a strong positive influence while Lecturer I, Lecturer II, Senior Lecturers, Associate Professors, and Professors are all seen to have weak negative influences on the probability of their discretionary behaviour. This suggests that variables in the model are all jointly significant. The implication of the above result is that, Graduate Assistants and Assistant Lecturers are more prone to engage in more DWB and less OCB as compared to Lecturer I and above, who are likely to engage in more of OCB and less DWB in federal universities of North-Central Nigeria.

\section{Table 5}

The Spread of Discretionary Behaviour among Academics of Federal Universities

\begin{tabular}{lcccccccc}
\hline Constructs & $\mathbf{r}$ & $\mathbf{t}$ & $\mathbf{d f}$ & \multicolumn{2}{c}{$\mathbf{9 5 \%}$ CI } & \multicolumn{2}{c}{ p-value } & \multicolumn{2}{c}{ Remarks } \\
\hline $\begin{array}{l}\text { Graduate } \\
\text { Assistant }\end{array}$ & 0.5700 & 3.924 & 32 & 0.2872 & 0.7614 & 0.0004 & $\mathrm{~S}$ & Strong \\
$\begin{array}{l}\text { Assistant } \\
\text { Lecturer }\end{array}$ & 0.5530 & 5.184 & 61 & 0.3537 & 0.7043 & 0.0001 & $\mathrm{~S}$ & Strong \\
Lecturer II & -0.0190 & -0.1319 & 48 & -0.2958 & 0.2607 & 0.8956 & N. S & Weak \\
\hline
\end{tabular}

(continued) 


\begin{tabular}{lcccccccc}
\hline Constructs & $\mathbf{r}$ & $\mathbf{t}$ & $\mathbf{d f}$ & $\mathbf{9 5 \%}$ CI & \multicolumn{2}{c}{ p-value } & \multicolumn{2}{c}{ Remarks } \\
\hline Lecturer I & 0.2841 & 2.1971 & 55 & 0.0254 & 0.5071 & 0.0322 & S & Weak \\
Senior & 0.1054 & 0.8678 & 67 & -0.1346 & 0.3338 & 0.3886 & N. S & Weak \\
Lecturer & & & & & & & & \\
Reader & -0.0746 & -0.2817 & 26 & -0.4356 & 0.3069 & 0.7058 & N. S & Weak \\
Professor & 0.3689 & 2.2455 & 32 & 0.0352 & 0.6287 & 0.0318 & S & Weak \\
N.S= not significant; S= significant & & & & \\
\hline
\end{tabular}

Source: This Study

The Pearson Correlation Matrix presented in Table 6 further shows the association between perceived BPC and discretionary behaviour of academics. The result revealed that there is a positive correlation between breach of psychological contracts and organisational citizenship behaviour, as well as positive relationship between BPC and deviant workplace behaviour $(\mathrm{r}=0.196 ; \mathrm{p}<0.05$, and $\mathrm{r}=0.126$; $\mathrm{p}<0.05$ ), respectively. This implied that a positive relationship subsists between the two construct variables, since the p-value is less than 0.05 . Since all the elements of perceived BPC have significant association with spread of discretionary behaviour, then the null hypothesis is rejected and the alternative hypothesis accepted, which states that perceived breach of psychological contract is significantly associated with the spread of discretionary behaviour among academics of federal universities in North-Central Nigeria.

\section{Table 6}

Results from the Pearson Correlation Test.

\begin{tabular}{llccc}
\hline \multicolumn{2}{l}{ Variables } & BPC & OCB1 & DWB1 \\
\hline BPC & Pearson Correlation & $.533^{* *}$ & $.317^{* *}$ & $.274^{* *}$ \\
& Sig. (2-tailed) & .000 & .000 & .000 \\
\multirow{5}{*}{ OCB1 } & N & 335 & 335 & 335 \\
& Pearson Correlation & $.196^{* *}$ & 1.000 & $.636^{* *}$ \\
& Sig. (2-tailed) & .000 & & .000 \\
& $\mathrm{~N}$ & 335 & 335 & 335 \\
DWB1 & Pearson Correlation & $.126^{*}$ & $.636^{* *}$ & 1.000 \\
& Sig. (2-tailed) & .021 & .000 & \\
& $\mathrm{~N}$ & 335 & 335 & 335 \\
\hline
\end{tabular}

Correlation 0.2911, t-test 5.5529, df 333, p-value 0.000, 95\%CI, Sig. $=0.000$ (2tailed) Source: This Study 


\section{Thematic Analyses of Results Obtained from Qualitative Data}

This section presents the result derived from qualitative data obtained from IDI, which was transcribed and analysed through thematic analysis. This was done in four stages namely; assembling of data, coding, sorting, and organisation of data to reduce errors. The following report of the thematic analysis was done based on responses obtained from 14 academic representatives (ASUU) and 14 Management staff who were interviewed.

\section{Theme 1: Adequacy of Facilities or Infrastructure for Teaching and Research in the University}

About $78.5 \%$ of the participants among academic representatives claimed that office spaces were inadequate and this made their work laboured. They desired expansion of the offices of academics to ease their research and teaching. Similarly, $92.8 \%$ of the respondents expressed dissatisfaction over poor work conditions and the quality of education available to students. The responses further showed that they perceived some elements of breach of psychological contract, which might have led to reduction in productivity and in some cases turnover intention. Mounting pressure on academics to teach and conduct research without providing them with teaching and research aids could lead to job dissatisfaction. The facilities and infrastructure were grossly inadequate and this is one of the problems in Nigerian federal universities. Management staff on the other hand, counterclaimed that offices provided for academics are sufficient to meet performance expectations. In addition, there was provision of social and other amenities for academics, despite the shortage of funds. They asserted that the institutions still strived to provide academics with good work conditions in order to meet their demands.

\section{Theme 2: Conflicts/Issues and Causes of BPC in the University}

Approximately $86 \%$ of academic representatives lamented that the failure of the government to implement the agreement signed with ASUU in 2009 is responsible for the persistent conflict. Other respondents (14\%) were of the opinion that when management or government fail to pay academics their entitlement as and when due, or when salaries/bonuses are delayed, these lecturers get demoralised. 
This is one of the reasons for frequently industrial action staged by the unions. The management staff on the other hand, reacted that the conflict between ASUU and employers has been an age long phenomenon which happens continually. They believed that academic staff habitually have one or two demands and that if and when those demands are not met or delayed, they will react by shutting down the university, which is not the best for the education system.

\section{Discussion of Findings}

The findings revealed that not all federal universities in North-Central Nigeria complies with the psychological contract, with the exception that the means of dispatching file/letters and treatment of academics as principal components of psychological contract tested positive in Levene's test, which shows that there is a significant relationship between the location of the university and organisational compliance with psychological contract in the federal universities $\left(\mathrm{R}^{2}=0.4927\right.$, $\mathrm{p}<0.05$ ). Hence, the null hypothesis was rejected while alternative hypothesis was accepted. This is corroborated by previous studies (Baharuddina, Ruzainy, Asyraf, Omara, \& Ismail, 2017; Sarwar, Awan, Alam, \& Anwar, 2010) that found relationships between the location and gender difference in discretionary behaviour of primary school teachers.

Findings further showed that all elements of perceived BPC have significant association with organisational citizenship behaviour $(\mathrm{r}=0.196 ; \mathrm{p}<0.05)$, as well as positive relationship between BPC and deviant workplace behaviour $(\mathrm{r}=0.126 ; \mathrm{p}<0.05)$. The null hypothesis was also rejected and the alternative hypothesis was accepted, which states that perceived breach of psychological contract is significantly associated with the spread of discretionary behaviour among academics of federal universities in North-Central Nigeria. This is in tandem with studies by Baharom, Sharfuddin, and Iqbal (2017), and Oyelakin and Agu (2017) who revealed significant factors, such as atmosphere of spirituality in the workplace and having employees' positive attitude to work and stay in an organisation.

In qualitative analysis, there was sufficient evidence that breach of psychological contract of federal universities in North-Central Nigeria influences academic discretionary behaviour. The findings 
gave an impression that university academics were dissatisfied with employment conditions, under-funding, and shortage of facilities and equipment, and most especially the conditions of service which had led to multiple industrial unrest, brain-drain, and turnover intention of high-skilled academics across various universities.

\section{Conclusion and Recommendations}

The study highlighted that BPC has influenced academics in different ways, showing a tendency for OCB and DWB. Unfortunately, the tendency for DWB outweighed that of OCB. For instance, when the university reneges on its promises or fail to do what they ought to do for academics, many academics may react negatively by engaging in deviant behaviour, such as abuse of teaching hours, misuse of official vehicles, Internet abuse, failure to attend statutory meetings, and sexual harassment among others. Conversely, when the university fails to uphold the promises made for the academics, results showed that several academics may tend to uphold organisational citizenship behaviour such as promoting the image of their university, help colleagues in resolving issues, working longer hours, increased punctuality, and showing tolerance, among others. Therefore, this study recommends that universities should increase their level of compliance with psychological contracts. Also, universities should establish policies to prevent increase in deviant workplace behaviour among academics. Given the revelation of the low representation of female academics, there should be an efficacy of a gender-based recruitment initiative to produce substantial increase in the percentage of female academics. The academics who uphold OCB despite the perceived BPC should be encouraged to sustain their good behaviour. These recommendations will increase academics' organisational citizenship behaviour and reduce the tendency for deviant workplace behaviour in federal universities.

\section{Theoretical and Practical Implications}

This study has successfully added new dimensions for prospective future researchers. These include,

a. the development of new research instruments from dimensions of OCB and DWB, which provide more precision in measurement, 
b. the establishment of the importance of maintaining academics' OCB after a breach of psychological contract by offering a sense of control to mitigate the potential negative impact of breach in Nigerian federal universities, and

c. the highlight of differences in responses to the perceived breach of psychological contract in universities and discretionary behaviour among academics ranging from Professors to Graduate Assistants in the university.

\section{Limitation and Suggestions for Further Studies}

There is a need for additional studies that include non-academics, likewise a wider coverage of universities in order to investigate more specifically how other non-academics perceive their breach of psychological contract compared to academic counterpart. This will reveal relationships between a breach of psychological contract and discretionary behaviour of non-academics. Despite some limitations of the study, the results offered support to the theoretical propositions and key objectives, and answered research questions, as well as provide gaps for future research on the area of breach of psychological contracts and discretionary behaviour. The study, however, drew recommendation, direction, and guidelines for future research where there is a need to examine and clarify these testable relationships.

\section{ACKNOWLEDGMENT}

This research received no specific grant from any funding agency in the public, commercial, or not-for profit sectors

\section{REFERENCES}

Ajzen, I. \& Fishbein, M. (2005). Attitude behaviour relations: A theoretical analysis and review of empirical research. Psychological Bulletin, 84, 888-918.

Anderson, V. (2009). Research methods in human resource management (2nd ed.). London: CIPD.

Animasahun, R. A., \& Aremu, S. O. (2017). Predictive estimates of psycho-socio-personal variables on organisational citizenship 
behaviour among personnel of NSCDC in Southwestern Nigeria. International Journal of Scientific Research in Education, 10(3), 295-310.

Anyim, F. C., Obisi, C., \& Aliyu, M. O. (2018). Deviant workplace behaviour in Nigeria: A conceptual and empirical analysis. Ilorin of Journal of Human Resource Management, 2(1), 73-88. Asamu, F. F., Abiola, J. A., Ogandimma, A., \& Bamidele, R. (2019). Industrial conflict and collective bargaining: Evidence from North-Central Region, Nigeria. International Journal of Mechanical Engineering and Technology, 10(3), 120-128.

Baharom, M. N., Sharfuddin, D. K., \& Iqbal, J. (2017). A systematic review on the deviant workplace behaviour. Review of Public Administration and Management, 5(3), 1-8.

Baharuddina, S. S., Ruzainy, M. N., Asyraf, M. A. Omara, N. E., \& Ismail, N. A. (2017). Psychological contract breach and psychological contract fulfilment on employee intention to quit. International Journal of Business Management, 2(1), 50-58.

Bambale, J. A., \& Shamsuddin, S. A. (2015). Psychological factors as predictors of turnover intention among employees of post consolidation banks in Nigeria. European Scientific Journal, 8(20), 81-95.

Bennett, R. J., \& Robinson, S. L. (2000). Development of a measure of workplace deviance. Journal of Applied Psychology, 85(3), 349-360.

Bennett, R. J., \& Robinson, S. L. (2003). The past, present and future of workplace deviance research. In J. Greenberg (Ed.), Organisational behaviour: The state of the science (2nd ed.). New Jersey: Pearson Education Limited.

Bichi, M. Y. (2004). Introduction to research methods and statistics (1st ed.). Kano: Debis and Co. Press and Publishing Company.

Blau, P. M. (1964). Exchange and power in social life. New York: Wiley and Sons Incorporated.

Bordens, S. K., \& Abbott, B. B. (2012). Research design methods: A process approach (5th ed.). New York: McGraw-Hill.

Chowdhury, D. (2015). Deviant citizenship behaviour: A comprehensive framework towards behavioural excellence in organisations. The East Asian Journal of Business Management, 5(1), 13-26.

Dunlop, P. D., \& Lee, K. (2004). Workplace deviance, organisational citizenship behaviour, and business unit performance: The bad 
apples do spoil the whole barrel. Journal of Organisational Behaviour, 25(1), 67-80.

Essays UK (2018). Psychological contract breach effects and violation on employees. Retrieved from https://www.ukessays.com/ essays/management/psychological-contract-breach-effectsand-vio lation-on-employees-management-essay.php?vref $=1$.

Faborode, M. O. (2016). Government must recognise education as the cornerstone for national development. The Chronicle of Education, 6(1), 45-67.

Fisher, C. M. (2004). Researching and writing a dissertation for business students. England: FT Prentice Hall.

Gomam, G. M., Vem, L. J., \& Panshak, R. G. (2017). Tetrad effect of perceived justice dimension on normative commitment, psychological ownership, and organisational deviant behaviour: A conceptual framework. International Journal of Advanced Scientific Research and Development, 4(4), 69-84.

Hastuti, D., Noor, I. M., Osman, A., \& Lubis, Z. (2017). Interacting effect openness to experience and perception of organisational politics on workplace deviant behaviour. Economac, 1(2), 1720.

Hasuli, P., \& Elaine, Y.C. (2018). The Mediating Mechanism between Psychological Contract Breach and Work-Related Outcomes: A Conceptual Framework. Journal of Vocational Behaviour, 49(3), 252-276.

Hill, H., Birley, G., \& McDougall, E. (2003). Research methods and statistics in psychology (3rd ed.). London: Hoder and Stoughton Limited.

Jaclyn, M. J., Richard, A. O., \& Ann, M. R. (2010). Psychological contracts and counterproductive work behaviours: employee responses to transactional and relational breach. Journal of Business and Psychology, 25(4), 555-568.

Kamil, N. M., \& Ahmad, K. (2018). Development of a scale for measuring the construct of organisational citizenship behaviour from the Islamic perspective. Malaysian Management Review, 49(1), 89-101.

Nigerian Universities Commission (NUC) (2018). List of Nigerian universities. Retrieved from https://nuc.edu.ng/nigerianuniverisities/federal-univeristies/

Norman, M. S., Avey, J. B., Nimnicht, J. L., \& Pigeon, N. G. (2010). The interactive effects of psychological capital and organisational 
identity on employee organisational citizenship and deviance behaviour, Organisational Studies, 17(4), 380-391.

Omar, F., Halim, F. W., Zayed, A. Z., Farhadi, H, Nasir R., \& Khairudin, R. (2016). Stress and job satisfaction as antecedents of workplace deviant behaviour. Worlds Applied Sciences Journal, 12(2), 46-51.

Organ, D. W. (1988). Organisational citizenship behaviour: The good soldier syndrome. Lexington, MA: Lexington Books.

Oyelakin, O., \& Agu, G. A. (2017). A mediating role of relational psychological contract on the relationship between work place spirituality and employee turnover intention in Nigeria banks. American Journal of Applied Psychology, 6(4), 75-82.

Pradhan, S., \& Pradhan, R. K. (2016). Workplace spirituality and deviant workplace behaviour: Lessons from age-old wisdom. Integrating Spirituality and Organisational Leadership, 7(2), 454-464.

Rousseau, D. M.(2003). Extending the psychology of the psychological contract: A reply to putting psychology back into psychological contracts. Journal of Management Inquiry, 12(2), 229-238.

Salau, O. P. (2017). Work environments and retention outcomes of state Universities in Southern Nigeria. Ph.D. Dissertation, Department of Industrial Relations and Human Resource Management, Covenant University, Ogun, Nigeria.

Sarwar, M., Awan, R., Alam, M., \& Anwar, M. N. (2010). Location and gender differences in deviant behaviour among primary school teachers. International Journal of Business and Management, 5(12), 97-101.

Ugwu, L. I., \& Oji, I. (2013). Psychological contract breach, workfamily conflict and self- efficacy as predictors of pro-social behaviour among a sample of Nigerian bank employees. International Review of Social Science and Humanities, 6(1), 135-145.

Waseem, M. (2016). Deviant workplace behaviour in organisations in Pakistan. The Lahore Journal of Business, 4(2), 93-104. 